\title{
ANALISIS KEPUASAN WISATAWAN LANJUT USIA TERHADAP PRODUK WISATA DI KAWASAN WISATA UBUD
}

\author{
Kadek Utami Wirya Adnyani \\ I Nyoman Sudiarta \\ I Putu Sudana \\ Email :wirya_adnyani@gmail.com \\ PS. S1 Industri Perjalanan Wisata \\ Fakultas Pariwisata UNUD
}

\begin{abstract}
ABSTRAK
Wisatawan lanjut usia memiliki potensi untuk melakukan kegiatan wisata, yang mana wisatawan pada usia ini telah mapan secara finansial serta memiliki waktu luang yang banyak. Wisatawan lanjut usia yang sedang berwisata ke Kawsan wisata Ubud memiliki keluhan mengenai kemacetan dan kurangnya toilet umum. Berdasarkan hal - hal tersebut maka dari itu perlu untuk mengetahui tingkat kepuasan wisatawan lanjut usia terhadap produk wisata di Kawasan Wisata Ubud dengan menggunakan konsep 4A yaitu atraksi, fasilitas, aksesibilitas, dan pelayanan tambahan. Fokus lokasi yang dijadikan tempat penyebaran kuesioner yaitu di Kelurahan Ubud. Pengumpulan data dilakukan dengan cara observasi, penyebaran kuesioner, wawancara, studi kepustakaan dan dokumentasi. Penyebaran kuesioner dilakukan kepada wisatawan lanjut usia mancanegara yang berusia 55 tahun keatas sebanyak 80 responden. Teknik analisis data yang digunakan yaitu deskriptif kuantitatif dengan menggunakan bantuan skala Likert, analisis tingkat kepentingan dan tingkat kinerja serta tingkat kesesuaian. Rata - rata tingkat kepuasan wisatawan lanjut usia terhadap produk wisata di Kawasan wisata Ubud adalah kurang puas dengan persentase sebesar $89,22 \%$, dengan rata - rata tingkat kepentingan $(\overline{\bar{Y}})$ yaitu 3,99 yang berarti penting dan rata - rata tingkat kinerja $(\overline{\bar{X}})$ adalah 3,54 dengan artian baik. Sedangkan faktor - faktor yang dianggap penting dan perlu mendapatkan prioritas dengan tingkat kesesuaian yang kecil adalah kondisi trotoar, ketersediaan toilet umum, dan ketersediaan penunjuk arah menuju destinasi wisata. Saran yang dapat diberikan baik itu pemerintah, penyedia jasa wisata, dan masyarakat agar memperhatikan faktor - faktor yang anggap penting tersebut, dan menyediakan fasilitas khusus untuk wisatawan lanjut usia, serta dapat bekerjasama dengan beberapa pihak seperti travel agent sehingga dapat meningkatkan kunjungan wisatawan lanjut usia ke Kawasan wisata Ubud.
\end{abstract}

Kata Kunci : Kepuasan Wisatawan, Wisatawan Lanjut Usia, Produk Wisata.

\section{PENDAHULUAN}

Pariwisata merupakan salah satu sektor pembangunan yang terus digalakkan dalam meningkatkan perekonomian bangsa. Di Indonesia sektor pariwisata telah menjadi komoditas yang mempunyai peran penting dalam pembangunan Indonesia khususnya sebagai penghasil devisa negara sektor non migas. Indonesia merupakan sebuah negara kepulauan yang memiliki banyak potensi besar dalam sektor kepariwisataanya baik itu potensi alam, bahari maupun wisatanya. Berdasarkan hal tersebut, Indonesia mampu menarik minat wisatawan mancanegara untuk melakukan perjalanan dan kunjungan ke Indonesia.

Pulau Bali adalah salah satu bagian dari Indonesia yang terkenal akan pariwisata budaya 
dan alamnya, banyak wisatawan yang berkunjung untuk menikmati atraksi wisata di pulau Bali mulai dari pantai, pegunungan, pedesaan, budaya, sejarah hingga makanan tradisional. Pulau ini banyak dikunjungi oleh wisatawan baik domestik maupun wisatawan mancanegara. Jumlah kunjungan wisatawan mancanegara ke Bali lima tahun terakhir dari tahun 2010 sampai dengan tahun 2014 mengalami peningkatan setiap tahunnya. Dari tahun 2010 ke tahun 2011 jumlah wisatawan meningkat sebesar 9,73\% kemudian tahun 2012 meningkat sebesar 4,34\% tahun 2013 meningkat sebesar $11,16 \%$ dan pada tahun 2014 merupakan tahun dengan tingkat kunjungan wisatawan asing tertinggi yaitu meningkat 14,89 . Rata-rata pertumbuhan wisatawan mancanegara yang berkunjung ke Bali dari tahun 2010 sampai tahun 2014 adalah sebesar 8,02 persen.

Bali juga menjadikan pariwisata sebagai sektor untuk meningkatkan perekonomian. Pariwisata di Bali telah tumbuh menjadi sebuah industri yang sangat menguntungkan dan memiliki prospek yang cerah dikemudian hari. Oleh karena itu pemerintah Bali kini mulai mengembangkan program di sektor pariwisata salah satunya "pariwisata lanjut usia" yang menjadikan wisatawan lanjut usia sebagai target pasar (beritadaerah.co.id, 2015). Pertumbuhan wisatawan lanjut usia pada segmen pasar pariwisata dari tahun ke tahun senantiasi mengalami peningkatan yang signifikan pada abad 21 ini. Berdasarkan data dari Dinas Pariwisata Bali dengan mengambil 1000 responden dari wisatawan yang berkunjung ke Bali pada tahun 2012 menunjukkan jumlah wisatawan mancanegara yang berkunjung ke Bali berdasarkan usia terlihat bahwakunjungan wisatawan dengan usia lebih dari 55 tahun yaitu sebesar 14,8\% dengan jumlah 148 orang. Padahal wisatawan dengan usia tersebut memiliki prospek yang bagusdanberpotensi melakukan kegiatan wisata. Kelompok usia ini memiliki waktu luang yang sangat besar sehingga memungkinkan mereka untuk berwisata dan tinggal lebih lama di suatu destinasi. Pada umumnya dengan sistem pensiun yang baik kelompok usia ini telah mapan secara finansial.

Kawasan wisata Ubud adalah lokasi yang sesuai untuk wisatawan lanjut usia dengan suasana pedesaan, tenang, serta lingkungan yang hijau (viptourbali.com, 2012). Kawasan wisata Ubud ini terletak di Kabupaten Gianyar, Kabupaten yang banyak memiliki banyak seniman dan dapat dikatakan merupakan pusat budaya seni di Bali, khususnya seni lukis, seni ukir, seni patung, seni tari dan musik traditional Bali.

Daya tarik wisata (DTW) merupakan tempat dimana segala kegiatan pariwisata bisa dilakukan dengan tersedianya segala fasilitas dan atraksi wisata untuk wisatawan.Dalam mendukung keberadaan DTW perlu ada unsur pokok yang harus mendapat perhatian guna wisatawan bisa tenang, aman, dan nyaman berkunjung. Semua ini sangat penting dalam meningkatkan pelayanan bagi wisatawan sehingga wisatawan bisa lebih lama tinggal di daerah yang dikunjungi. Adapun unsur pokok tersebut yaitu: objek dan daya tarik wisata, prasarana wisata, sarana wisata, tata laksana/infrastruktur dan masyarakat/ lingkungan (Suwena dan Widyatmaja, 2010: 83). Kawasan wisata Ubud tentunya memiliki unsur pokok yang menunjang kegiatan pariwisata seperti akomodasi, transportasi, aksesbilitas, tempat makan, pusat informasi, pusat perbelanjaan dan lain sebagainya. Dengan segala unsur - unsur pokok yang disediakan diharapkan mampu memberikan kepuasan dan meningkatkan kunjungan wisatawan lanjut usia.

Kepuasan menjadi salah satu faktor yang penting dalam menciptakan loyalitas, hal ini dibuktikan dari hasil penulisan desertasi yang dilakukan oleh Rai Utama (2014) dengan judul Loyalitas Wisatawan Mancanegara Lanjut Usia Berwisata di Bali yang menyatakan bahwa kepuasan wisatawan mancanegara lanjut usia sangat berpengaruh signifikan terhadap loyalitas wisatawan mancanegara lanjut uisa berkunjung ke Bali dengan hasil 91\% wisatawan lanjut usia masih berniat untuk datang kembali, 92\% bersedia merekomendasikan Bali kepada teman - temannya, dan jika dilihat dari frekuensi kunjungan wisatawan lanjut usia sebesar $81 \%$ merupakan repeater guest.Dengan terciptanya loyalitas wisatawan lanjut usia tentunya akan dapat meningkatkan kunjungan wisatawan lanjut usia khususnya ke Kawasan wisata Ubud. 
Berdasarkan hasil observasi yang telah dilakukan oleh Utami mengenai tanggapan wisatawan lanjut usia terhadap produk wisata di kawasan wisata Ubud pada bulan Mei tahun 2015, beberapa wisatawan lanjut usia menyatakan bahwa secara umum puas terhadap produk wisata yang sudah disediakan sehingga dengan rasa puas tersebut memungkinkan wisatawan lanjut usia ini untuk datang kembali ke kawasan wisata Ubud. Namun terdapat beberapa keluhan dari wisatawan lanjut usia salah satunya yaitu kemacetan, kondisi kendaraan yang crowded dapat menimbulkan rasa kurang aman bagi para wisatawan lanjut usia dalam berwisata serta susahnya menemukan toilet umum di area destinasi. Masalah yang ada tentunya dapat memberikan kesan negatif dan berpengaruh terhadap kunjungan wisatawan lanjut usia ke kawasan wisata Ubud.Oleh karena itu pengukuran kepuasan wisatawan lanjut usia mancanegara terhadap produk wisata di Kawasan wisata Ubud perlu dilakukan guna mengidentifikasi faktor - faktor penting yang dibutuhkan oleh wisatawan lanjut usia selama berkunjung ke Kawasan wisata Ubud. Maka dari itu perlu diketahui lebih lanjut untuk mengetahui tingkat kepuasan wisatawan lanjut usia terhadap produk wisata dalam meningkatkan kunjungannya ke Kawasan wisata Ubud.

\section{METODE}

Lokasi yang menjadi fokus penyebaran kuesioner yaitu pada daerah Monkey Forest, Puri Ubud dan Pasar Ubud. Wisatawan akan menilai kepuasannya terhadap 4 variabel produk wisata (atraksi, fasilitas, aksesibilitas, dan pelayanan tamabahan) yang dikembangkan menjadi 16 indikator. Kepuasan wisatawan akan dinilai berdasarkan tingkat kinerja yang diwakili oleh $\mathrm{X}$ dan tingkat kepentingan yang di wakili oleh Y. Teknik penentuan informan dan sampel menggunakan teknik purposive sampling dan accidental sampling dengan jumlah sampel sebanyak 80 responden yang mana respondennya adalah wisatawan lanjut usia mancanegara yang berusia 55 tahun keatas.

Teknik analisis daya yang digunakan yaitu deskriptif kuantitatif yang dibantu dengan teknik skala Likert.Untuk tingkat kepentingan dan kinerja masing - masing indikator memiliki gradasi nilai yaitu nilai 1 (tidak baik/ tidak penting) dengan skala interval $1,00-1,80,2$ (kurang baik/ kurang penting) dengan skala interval $1,81-2,60,3$ (cukup baik/cukup penting) dengan skala interval 2,61 - 3,40, 4 (baik/ penting) dengan skala interval 3,41-4,20, 5 (sangat baik/ sangat penting) dengan skala interval 4,21 - 5,00, selisih masing - masing skala sikap adalah 0,80. Hasil penilaian wisatawan lanjut usia mengenai tingkat kepentingan dan kinerja maka akan dihitung tingkat kesesuaiannya untuk mengetahui tingkat kepuasannya, kemudian dihitung rata - rata $\mathrm{X}$ dan Y nya. Setelah itu membuat sebuah diagram kartesius dengan mencari rata - rata dari rata rata tingkat kepentingan $\overline{\bar{Y}}$ dan tingkat kinerja $\overline{\bar{X}}$ untuk menentukkan titik yang akan membagi diagram kartesius ke dalam 4 kuadran.

\section{PEMBAHASAN}

Pada Tabel 1 menunjukkan hasil karakteristik dari 80 responden sebagai berikut.

\begin{tabular}{|c|c|c|c|}
\hline Karakteristik & Pilihan & Jumlah & $\%$ \\
\hline \multirow{2}{*}{ Jenis Kelamin } & Laki-laki & 46 & 57,5 \\
\hline & Perempuan & 34 & 42,5 \\
\hline \multirow{3}{*}{ Kelompok Umur } & $55-59$ & 33 & 41,25 \\
\hline & $60-64$ & 21 & 32,5 \\
\hline & 65 keatas & 26 & 26,25 \\
\hline \multirow{12}{*}{ Kewarganegaraan } & Australia & 18 & 22,5 \\
\hline & Perancis & 13 & 16,25 \\
\hline & Belanda & 11 & 13,75 \\
\hline & Amerika & 7 & 8,75 \\
\hline & Swiss & 7 & 8,75 \\
\hline & Jerman & 6 & 7,5 \\
\hline & Inggris & 3 & 3,75 \\
\hline & New Zealand & 3 & 3,75 \\
\hline & Kanada & 2 & 2,5 \\
\hline & Spanyol & 2 & 2,5 \\
\hline & Italia & 2 & 2,5 \\
\hline & Lainnya & 6 & 7,5 \\
\hline \multirow{5}{*}{ Lama tinggal } & $1-7$ hari & 13 & 16,25 \\
\hline & $8-14$ hari & 27 & 33,75 \\
\hline & $15-21$ hari & 26 & 32,5 \\
\hline & $22-28$ hari & 6 & 7,5 \\
\hline & $>28$ hari & 8 & 10 \\
\hline \multirow{9}{*}{ Pekerjaan } & Pensiunan & 33 & 41,25 \\
\hline & Guru & 16 & 20 \\
\hline & Pekerja Swasta & 10 & 12,5 \\
\hline & Pekerja Seni & 6 & 7,5 \\
\hline & Insinyur & 4 & 5 \\
\hline & Kedokteran & 3 & 3,75 \\
\hline & Akuntan & 2 & 2,5 \\
\hline & Pemeintahan & 2 & 2,5 \\
\hline & Lainnya & 4 & 5 \\
\hline \multirow{3}{*}{ Status Pernikahan } & Single & 10 & 12,5 \\
\hline & Menikah & 63 & 78,75 \\
\hline & Bercerai & 7 & 8,75 \\
\hline \multirow[b]{2}{*}{ Sumber Pendapatan } & Pensiun & 29 & 36,25 \\
\hline & $\begin{array}{ll}\begin{array}{l}\text { Bekerja/ } \\
\text { saving }\end{array} & \text { own } \\
\end{array}$ & 51 & 63,75 \\
\hline \multirow{4}{*}{ Status Ekonomi } & Sangat Kaya & 6 & 7,5 \\
\hline & Kaya & 28 & 35 \\
\hline & Cukup & 45 & 56,25 \\
\hline & Sulit & 1 & 1,25 \\
\hline \multirow{4}{*}{ Frekuensi Kunjungan } & 1 kali & 48 & 60 \\
\hline & 2 kali & 14 & 17,5 \\
\hline & 3 kali & 4 & 5 \\
\hline & $>3 \mathrm{kali}$ & 14 & 17,5 \\
\hline
\end{tabular}


Pada 1 dapat terlihat bahwa wisatawan lanjut usia yang datang ke Kawasan wisata Ubud didominasi dengan jenis kelamin laki laki sebesar 57,5\% dengan kelompok umur terbanyak yaitu umur 55 - 59 sebesar $41,25 \%$. Kewarganegaraan wisatawan lanjut usia paling banyak datang dari Negara Australia sebesar $22,5 \%$, lama tinggal wisatawan lanjut usia di Bali yaitu terbanyak selama $8-14$ hari sebesar $33,75 \%$, dengan pekerjaan paling banyak yaitu pensiunan sebesar 41,25\%. Status responden didominasi oleh responden dengan status menikah, dengan sumber pendapatan terbanyak yaitu dari bekerja/ own saving sebesar $63,75 \%$. Kemudian untuk status ekonomi didominasi dengan status cukup sebesar $56,25 \%$ dan frekuensi kunjungan paling banyak sebanyak satu kali dengan persentase $60 \%$.

Selanjutnya hasil analisis data dapat dilihat pada Tabel 2 sebagai berikut.

Tabel 2. Hasil Analisis data

\begin{tabular}{|c|c|c|c|c|c|c|}
\hline Indikator & $\begin{array}{c}\text { Skor } \\
\mathbf{Y}\end{array}$ & $\begin{array}{c}\text { Skor } \\
\text { X }\end{array}$ & $\overline{\overline{\mathbf{Y}}}$ & $\overline{\overline{\mathbf{X}}}$ & $\begin{array}{l}\text { Tki } \\
(\%)\end{array}$ & $\begin{array}{c}\text { Pri } \\
\text { orit } \\
\text { as } \\
\end{array}$ \\
\hline $\begin{array}{l}\text { 1. Keindahan } \\
\text { destinasi } \\
\text { wisata }\end{array}$ & 339 & 318 & 4,23 & 3,97 & 93,8 & VII \\
\hline $\begin{array}{ll}\text { 2. } & \text { Atraksi } \\
\text { kesenian } \\
\text { tradisional }\end{array}$ & 320 & 320 & 4 & 4 & 100 & $\mathrm{XI}$ \\
\hline $\begin{array}{l}\text { 3. Atraksi } \\
\text { upacara dan } \\
\text { budaya }\end{array}$ & 330 & 311 & 4,12 & 3,88 & 94,2 & IX \\
\hline $\begin{array}{l}\text { 4. Variasi daya } \\
\text { tarik wisata }\end{array}$ & 334 & 314 & 4,17 & 3,92 & 94 & VIII \\
\hline $\begin{array}{l}\text { 5. Ketersediaan } \\
\text { akomodasi }\end{array}$ & 304 & 326 & 3,8 & 4,07 & 107,2 & XV \\
\hline $\begin{array}{l}\text { 6. Variasi pilihan } \\
\text { rumah makan }\end{array}$ & 332 & 339 & 4,15 & 4,23 & 102,1 & $\begin{array}{c}\mathrm{X} \\
\mathrm{IV} \\
\end{array}$ \\
\hline $\begin{array}{l}\text { 7. Ketersediaan } \\
\text { transportasi } \\
\text { umum } \\
\end{array}$ & 276 & 265 & 3,45 & 3,31 & 96 & $\mathrm{X}$ \\
\hline $\begin{array}{l}\text { 8. Ketersediaan } \\
\text { money } \\
\text { changer }\end{array}$ & 302 & 326 & 3,77 & 4,07 & 107,9 & $\begin{array}{c}\mathrm{X} \\
\mathrm{VI}\end{array}$ \\
\hline $\begin{array}{l}\text { 9. Kenyamanan } \\
\text { pada tempat } \\
\text { perbelanjaan }\end{array}$ & 317 & 320 & 3,96 & 4 & 100,9 & XII \\
\hline $\begin{array}{c}\text { 10. Ketersediaan } \\
\text { toilet umum }\end{array}$ & 330 & 218 & 4,12 & 2,72 & 66,06 & II \\
\hline $\begin{array}{l}\text { 11. Ketersediaan } \\
\text { penunjuk arah }\end{array}$ & 328 & 237 & 4,1 & 2,96 & 72,2 & III \\
\hline $\begin{array}{l}\text { 12. Kondisi } \\
\text { infrastruktur }\end{array}$ & 316 & 231 & 3,95 & 2,88 & 73,1 & IV \\
\hline $\begin{array}{l}\text { 13. Ketersediaan } \\
\text { lampu } \\
\text { penerangan } \\
\end{array}$ & 288 & 234 & 3,6 & 2,92 & 81,2 & $\mathrm{~V}$ \\
\hline $\begin{array}{c}\text { 14. Kondisi } \\
\text { trotoar }\end{array}$ & 354 & 160 & 4,42 & 2 & 45,1 & I \\
\hline $\begin{array}{l}\text { 15.Pelayanan } \\
\text { pusat } \\
\text { informasi } \\
\text { wisata }\end{array}$ & 294 & 273 & 3,67 & 3,41 & 92,8 & VI \\
\hline
\end{tabular}

\begin{tabular}{|c|c|c|c|c|c|c|}
\hline $\begin{array}{c}\text { 16.Keramahan } \\
\text { pegawai di } \\
\text { destinasi } \\
\text { wisata }\end{array}$ & 351 & 355 & 4,38 & 4,43 & 101,1 & $\begin{array}{c}\text { X } \\
\text { III }\end{array}$ \\
\cline { 1 - 5 } Total & $\mathbf{5 1 1 5}$ & $\mathbf{4 5 4 7}$ & $\begin{array}{c}\mathbf{6 3 , 8} \\
\mathbf{9}\end{array}$ & $\begin{array}{c}\mathbf{5 6 , 7} \\
\mathbf{7}\end{array}$ & $\mathbf{1 4 2 7 , 7}$ & \\
\cline { 1 - 5 } Rata - rata & $\mathbf{3 1 9 , 6}$ & $\mathbf{2 8 4 , 1}$ & $\mathbf{3 , 9 9}$ & $\mathbf{3 , 5 4}$ & $\mathbf{8 9 , 2 2}$ & \\
\hline
\end{tabular}

Hasil yang ditunjukkan pada Tabel 2 diatas menunjukkan hasil dari perhitungan tingkat kinerja, tingkat kepentingan dan tingkat kesesuaian serta tingkat prioritas berdasarkan tingkat kesesuaiannya. Nilai yang ditunjukkan pada Tabel 2 yang menjadi indikator paling penting yaitu kondisi trotoar, sedangkan indikator yang paling baik yaitu indikator keramahan pegawai di destinasi wisata dan tingkat kesesuaian yang paling besar adalah ketersediaan money changer.

Berdasarkan dari data diatas, perhitungan skala interval yang dihitung untuk tingkat kepentingan (Y) menunjukkan bahwa terdapat 3 indikator yang dianggap sangat penting oleh wisatawan, 12 indikator yang dianggap penting, dan 1 indikator yang dianggap cukup penting. Berdasarkan perhitungan skala interval yang dihitung untuk tingkat kinerja $(\mathrm{X})$ menunjukkan bahwa terdapat 2 indikator yang dirasa sangat baik oleh responden, 9 indikator yang kinerja dirasa baik, 4 indikator dirasa kinerjanya cukup baik, dan ada 1 indikator yang kinerjanya dirasa kurang baik. Namun berdasarkan tingkat kesesuaiannya hasil perbandingan dari skor $\mathrm{X}$ dan skor $\mathrm{Y}$ itu menunjukkan bahwa ada 5 indikator yang dirasa sangat puas hal ini dikarenakan tingkat kinerjanya melebihi tingkat kepentingan atau harapan dari wisatawan lanjut usia, ada 1 indikator yang tingkat kinerjanya telah sesuai dengan tingkat kepentingannya yang berarti wisatawan puas terhadap indikator tersebut. Sedangkan ada 10 indikator yang dirasa kurang puas yang berarti tingkat kinerjanya belum sesuai dengan tingkat kepentingannya.

Berdasarkan dari rata - rata tingkat kesesuaian didapatkan hasil tingkat kepuasan wisatawan lanjut usia yaitu sebesar $89,22 \%$ yang berarti wisatawan lanjut usia mancanegara ini kurang puas atau kecewa dengan produk wisata yang ada di Kawasan wisata Ubud. Hal ini dikarenakan hasil dari tingkat kinerjanya 
lebih rendah dibanding tingkat kepentingan serta hasil rata - rata tingkat kesesuaian menunjukkan kurang dari $100 \%$. Untuk mengetahui tingkat prioritas berdasarkan perbandingan tingkat kepentingan dan tingkat kinerja dapat dilihat pada diagram kartesius Gambar 1 berikut.

Gambar 1. Diagram Kartesius

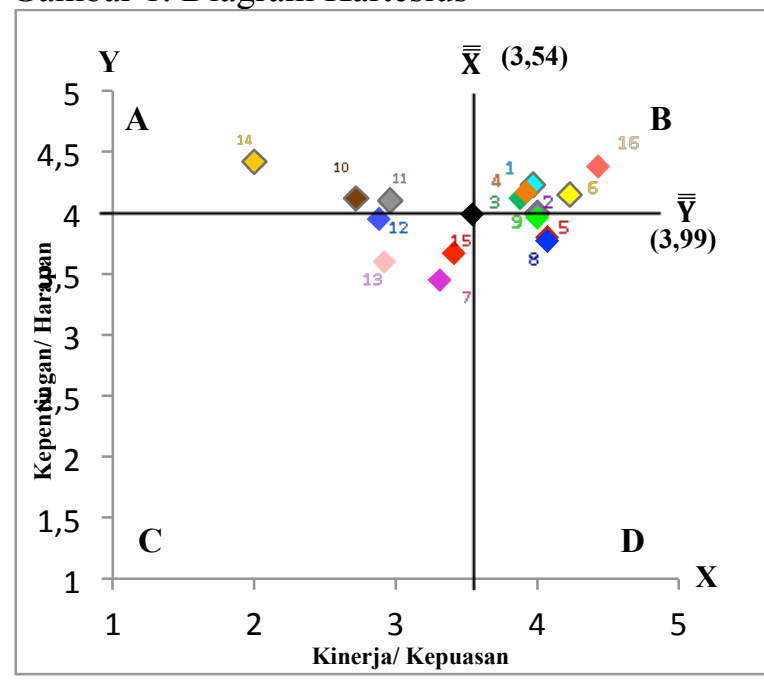

Berdasarkan diagram kartesius pada Gambar 1 diatas menunjukkan bahwa letak dari faktor - faktor yang mempengaruhi kepuasan wisatawan lanjut usia terhadap produk wisata di Kawasan wisata Ubud terbagi ke dalam empat kuadran. Adapun interprestasi diagram kartesius dapat dijelaskan bahwa indikator yang berada pada kuadran Adianggap sangat penting dan perlu mendapatkan prioritas utama dari perusahaan/ pemerintah, yang termasuk kedalam kuadran ini yaitu: ketersediaan toilet umum (10), ketersediaan penunjuk arah ke destinasi (11), dan kondisi trotoar (14). Sedangkan indikator pada kuadran B adalahindikator yang perlu dipertahankan prestasinya yang mana indikator - indikator ini penting dan pelaksanaannya juga telah memuaskan, yang masuk kedalam kuadran iniyaitu: keindahan destinasi wisata (1), atraksi kesenian tradisional (2), atraksi upacara dan budaya (3), keragaman destinasi wisata (4), variasi pilihan rumah makan (6), dan keramahan pegawai pada destinasi wisata (16). Kemudian indikator pada kuadran $\mathrm{C}$ adalah indikator yang menjadi prioritas rendah, dimana dinilai kurang penting oleh wisatawan lanjut usia sedangkan tingkat pelaksanaannya memuaskan, yang berada pada kuadran ini yaitu: ketersediaan transportasi umum (7), kondisi infrastruktur jalan menuju destinasi wisata (12), ketersediaan lampu penerangan (13), dan pelayanan pusat informasi wisata (15). Kemudian yang berada pada kuadran D merupakan indikator yang dinilai berlebihan karena dianggap kurang penting oleh wisatawan lanjut usia namun tingkat pelaksanaannya sangat memuaskan oleh wisatawan lanjut usia, yaitu: ketersediaan akomodasi (5), ketersediaan money changer (8), dan kenyamanan pada tempat perbelanjaan/ shopping facilities (9).

Sedangkan berdasarkan tingkat kesesuaian yang menjadi tingkat prioritas indikator produk wisata di Kawasan wisata Ubud yang utama yaitu kondisi trotoar sebesar $45,1 \%$ dan yang memiliki persentase terbesar dan menjadi prioritas terakhir adalah indikator ketersediaan money changer dengan persentase 107,9. Semakin kecil hasil persentase maka indikator tersebut semakin diprioritaskan begitu pula sebaliknya semakin besar hasil tingkat kesesuaiannya maka prioritasnya semakin kecil.

\section{SIMPULAN DAN SARAN Simpulan}

Berdasarkan data yang diperolehdari 80 responden wisatawan lanjut usia mancanegara dapat disimpulkan bahwa tingkat kepuasan wisatawan lanjut usia terhadap produk wisata di Kawasan wisata Ubud yaitu sebesar 89,22\% yang berarti bahwa wisatawan lanjut usia merasa kecewa atau kurang puas dikarenakan hasil tingkat kesesuaian berada di bawah $100 \%$. Rata - rata dari rata - rata tingkat kepentingan $(\overline{\bar{Y}})$ yang dihasilkan yaitu sebesar 3,99 sedangkan dan rata - rata dari rata - rata tingkat kinerja $(\overline{\bar{X}})$ adalah 3,54. Berdasarkan hasil diagram kartesius dan urutan tingkat prioritas berdasarkan tingkat kesesuaian terdapat tiga indikator yang dianggap penting serta perlu mendapatkan prioritas utama adalah kondisi trotoar dengan tingkat kesesuaian sebesar $45,1 \%$, selanjutnya yang perlu mendapat prioritas utama 
adalah ketersediaan toilet umum dengan tingkat kesesuaian $66,06 \%$ dan faktor ketiga yang perlu mendapat prioritas utama yaitu faktor ketersediaan penunjuk arah menuju destinasi wisata dengan persentase sebesar $72,2 \%$.

\section{Saran}

Dari hasil yang telah dipaparkan maka ada beberapa saran yang dapat diberikan yang sekiranya dapat membantu serta bermanfaat bagi pihak - pihak yang berkepentingan, yaitu: agar pelaku pariwisata baik itu pemerintah, penyedia jasa wisata dan masyarakat dapat memperhatikan 3 faktor yang perlu mendapatkan prioritas utama, mempertahankan prestasi faktor - faktor yang sudah memenuhi kepuasan wisatawan lanjut usia, selain itu diharapkan dapat menyediakan fasilitas khusus yang diperlukan wisatawan lanjut usia serta dapat bekerja sama dengan pihak travel agent untuk dapat mengembangkan dan meningkatkan kunjungan wisatawan lanjut usia ke Kawasan wisata Ubud.

\section{DAFTAR PUSTAKA}

Cooper, Chris, John Fletcher, David Gilbert, dan Stephen Wanhill. 1993. Tourism Principles \& Practice. London: Pitman Publishing.

Esichaikul, Ranee. 2012. Travel Motivations, Behavior and Requirements of European Senior Tourists to Thailand. Sukhothai. Journal of Thammathirat Open University (Thailand).

Supranto, J. 2006. Pengukuran Tingkat Kepuasan Pelanggan untuk Menaikkan Pangsa Pasar. Jakarta: PT Rineka Cipta

United Nation - World Tourism Organization (WTO). 2005. Tourism Highlight UNWTO, Tourism Barometer Volume 12.

Utama, I Gusti Bagus Rai.2014. Loyalitas Wisatawan Mancanegara Lanjut Usia Berwisata di Bali. Disertasi. Universitas Udayana.

Anonim. Seratus Ribu Wisatawan Lansia Investasi langsung $R p \quad 100$ Trilyun. www.viptourbali.com/seratus-ribuwisatawan-lansia-investasi-langsung-rp- 100-trilyun/ diakses pada tanggal 5 Juni 2015.

Dinas Pariwisata Pemerintah Provinsi Bali.2015. Statistik.http://www.disparda.baliprov.go. $\mathrm{id} / \mathrm{id} /$ Statistik2 diakses pada tanggal $14 \mathrm{Mei}$ 2015.

Purba, Agustinus. 2015. Bali Akan Mengembangkan Wisata Bagi Lansia. http://beritadaerah.co.id/2015/01/17/baliakan-mengembangkan-wisata-bagi-lansia diakses pada tanggal 14 Juni 2015. 